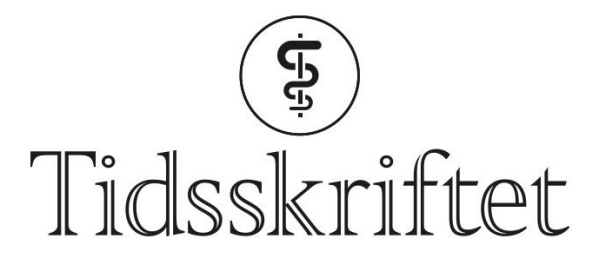

DEN NORSKE LEGEFORENING

\title{
Pakking av kromosomer før celledeling
}

FRA ANDRE TIDSSKRIFTER

RUTH HALSNE

Tidsskriftet

Proteinkompleksene condensin I og condensin II er viktige for å sikre kromatinstrukturen ved celledeling.

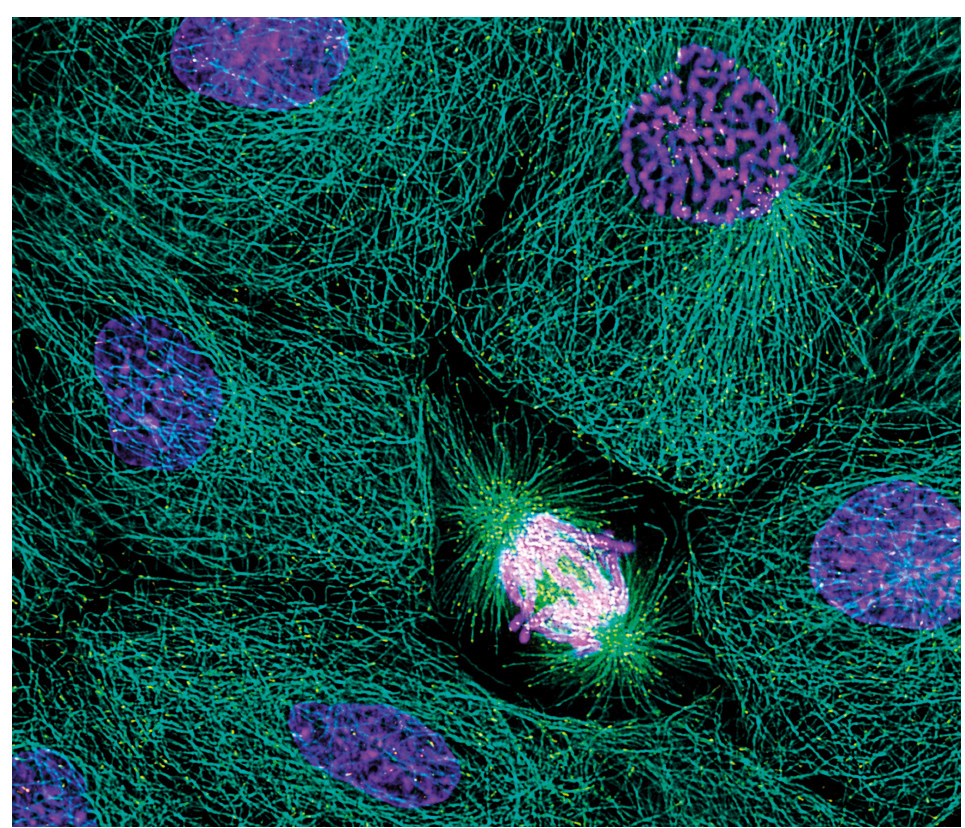

Cellemitose, her i anafasen. Illustrasjonsfoto: Science photo library/NTB Scanpix.

Ved celledeling - mitose - organiseres DNA i tettpakkede kromatinstrukturer for å sikre overføring av arvematerialet. I en studie som nylig er publisert i tidsskriftet Science, ble såkalte DT40-celler fra kylling brukt for å studere denne prosessen (1). Ved å hindre aktiviteten til cyklinavhengig kinase 1 (CDK1) ble cellene stoppet i G2-fasen i cellesyklus og slik synkronisert inn i mitosen. Cellene ble stoppet ved ulike tidspunkt for å undersøke den tredimensjonale strukturen av kromosomene. Cellene ble fiksert med formaldehyd som sørger for kryssbinding av DNA og protein, slik at man kan følge endringer av kontaktpunkter i kromatinstrukturen. Sammen med mikroskopibilder ble pakkingen av kromosomene kartlagt. Ved å fjerne condensin I og condensin II, to proteinkomplekser som er involvert i mitosen, fant man den spesifikke rollen disse kompleksene spiller.

- Denne studien har gjennom intrikate metoder gitt forståelse for prosessene som fører til 
at kromosomene pakkes tett sammen ved celledeling, sier Ragnhild Eskeland, som er forsker ved Institutt for biovitenskap, Universitetet i Oslo, og Senter for kreftcellereprogrammering.

- Alle celler pakker arvematerialet i kromatin, og genenes plassering i cellekjernen er organisert og gruppert etter aktiviteten deres. Genenes plassering er altså ikke tilfeldig. I mitosen opphører hele denne organiseringen, og kromosomene tvinnes opp som i en vindeltrapp, der trappetrinnene er løkker av kromatin, forklarer Eskeland. - Funnene viser hvordan condensin I og II regulerer pakkingen av kromosomene. Dette kan illustreres ved hjelp av vindeltrappmodellen. Condensin II binder DNA, lager kromatinløkker, danner en søyle i trappens senter og regulerer dermed avstanden mellom trappetrinnene. Condensin I binder kromatinløkkene lenger ute og regulerer størrelsen på trappetrinnene. Condensin I binder altså ytre kromatinløkker, mens condensin II binder indre kromatinløkker. De to har altså ulike roller i pakkingen av kromosomene til den lett gjenkjennelige kromosomstrukturen i celledelingen, sier Eskeland, som håper det blir mulig å identifisere flere condensinuavhengige pakkemekanismer og deres samspill med condensin.

\section{LITTERATUR:}

1. Gibcus JH, Samejima K, Goloborodko A et al. A pathway for mitotic chromosome formation. Science 2018; 359: eaao6135. [PubMed][CrossRef]

Publisert: 12. oktober 2018. Tidsskr Nor Legeforen. DOI: 10.4045/tidsskr.18.06o9

(C) Tidsskrift for Den norske legeforening 2020. Lastet ned fra tidsskriftet.no 